\title{
Antenatal screening for candidiasis, trichomoniasis, and gonorrhoea
}

\author{
R. A. SPARKS, G. L. WILliaMS, J. M. H. BOYCE, T. C. FITZGERALD, \\ AND G. SHELLEY \\ St. David's Hospital, Cowbridge Road East, Cardiff, CF1 9TZ
}

Most pregnant women have a vaginal discharge, which may be physiological or pathological.

Candidiasis is common and occasionally intractable in pregnancy. The chief importance of diagnosis and successful treatment is to prevent the uncommon, but serious sequela, of infection of the foetus and placenta in utero (Albarracin, Patterson, and Daria Haust, 1967). This is usually associated with premature labour.

Trichomoniasis can also affect the newborn. Infection of the vagina (Crowther, 1962) and urinary tract (Littlewood and Kohler, 1966) has been described in neonates. There is an association between trichomoniasis and dyskaryotic cervical smears (De Carneri and Di Re, 1970).

The prevalence of gonorrhoea has increased over the past 20 years throughout the world. The figures for females for England and Wales are shown in Fig. 1 and a comparison between 1968 and 1972 is given in Table I (Chief Medical Officer, 1970, 1974).

TABLE I Post-pubertal female gonorrhoea in 1968 and 1972 i.e. excluding vulvo-vaginitis in children and ophthalmia neonatorum

\begin{tabular}{|c|c|c|c|}
\hline \multirow{2}{*}{ Age group } & \multicolumn{2}{|c|}{ Incidence per 100,000 population } & \multirow{2}{*}{$\begin{array}{l}\text { Percentage } \\
\text { increase }\end{array}$} \\
\hline & 1968 & 1972 & \\
\hline $\begin{array}{l}\text { All ages } \\
\text { Under } 16 \\
16 \text { and } 17 \\
18 \text { and } 19 \\
20 \text { to } 24 \\
25 \text { and over }\end{array}$ & $\begin{array}{r}50.94 \\
4.19 \\
193.92 \\
315 \cdot 22 \\
248.22 \\
27.66\end{array}$ & $\begin{array}{r}77 \cdot 10 \\
7 \cdot 36 \\
362 \cdot 92 \\
575 \cdot 43 \\
393 \cdot 06 \\
36 \cdot 26\end{array}$ & $\begin{array}{l}52 \\
76 \\
87 \\
83 \\
58 \\
31\end{array}$ \\
\hline
\end{tabular}

The most dramatic rise in prevalence of gonorrhoea has occurred in women under 20 years of age. This age group contains the largest proportion of the unmarried and these are the young women most likely to present in the antenatal clinic with an illegitimate pregnancy.

Screening for gonorrhoea in pregnancy has mainly been undertaken in North America, where the prevalence varies from 2.5 to 7.3 per cent. (Waters

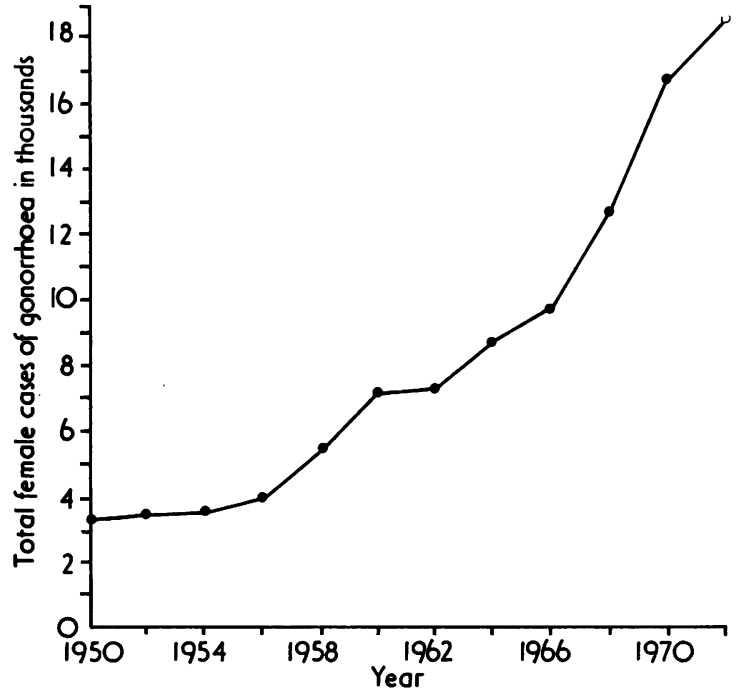

FIGURE Increase in total female cases of gonorrhoea in England and Wales, 1950-1972

and Roulston, 1969; Charles, Cohen, Kass, and Richman 1970). In Great Britain, Thin and Michael (1970) found none, Rees and Hamlett (1972) found 0.6 per cent., Cassie and Stevenson (1973) found 0.2 per cent., and Silverstone, Snodgrass, and Wigfield (1974) found none.

\section{Patients and methods}

625 consecutive antenatal patients were investigated at the booking and routine antenatal clinics between October, 1971, and July, 1972. 405 of these were asked if they had a vaginal discharge and, for those answering in the affirmative, an attempt was made (by R.A.S.) to reach a clinical diagnosis-candidiasis, trichomoniasis, or non-specific discharge.

An unlubricated Cusco speculum was inserted and the cervix and vagina inspected.

Secretion from the upper vagina was obtained with a sterile serum-coated swab and broken off into Trichomonas Medium No. 2 (Oxoid). In the 405 patients questioned about discharge, the swab was first plated directly onto 2,3,5,-triphenyltetrazolium chloride (TTC) agar (prepared 
by the addition to Pagano-Levine Agar (Difco) of 0.01 per cent. 2,3,5,-triphenyltetrazolium chloride and 500 $\mu \mathrm{g} . / \mathrm{ml}$. neomycin) and then inoculated into the Trichomonas Medium No. 2.

Samples from inside the cervical canal were obtained either with a sterile serum-coated swab or a presterilized plastic disposable loop (Sterilin) and spread immediately onto pre-warmed G.C. Selective Medium (Oxoid) containing trimethoprim $5 \mu \mathrm{g} . / \mathrm{ml}$., vancomycin $3 \mu \mathrm{g} . / \mathrm{ml}$., nystatin $12.5 \mu \mathrm{g} . / \mathrm{ml}$., and colistin sulphomethate $8 \mu \mathrm{g} . / \mathrm{ml}$. This medium is used routinely for the selection of pathogenic Neisseria species. Before inoculation all culture plates were kept in a $37^{\circ} \mathrm{C}$. bench incubator for at least $30 \mathrm{~min}$. and after inoculation were replaced immediately in the incubator while awaiting transport to the laboratory. During transit to the laboratory, the plates were out of the incubator for a maximum of 2 to 3 minutes.

A further sample of cervical discharge was smeared onto a glass slide and allowed to dry.

A cervical smear was taken from the squamo-columnar junction of the cervix with an Ayre spatula. The material was spread on a glass slide and fixed with water-soluble carbowax in alcohol.

After the speculum was removed, a sample of secretion from within the urethra was collected with a sterile swab or loop and plated directly onto G.C. Selective Medium and a smear was made.

The presence of any other sexually-transmissible condition was noted.

Blood was taken for the Wassermann reaction, and the Kahn and Reiter protein complement-fixation tests.

The TTC plates were incubated for $48 \mathrm{hrs}$ at $37^{\circ} \mathrm{C}$., after which the plasma test (Taschdjian, Burchell, and Kozinn, 1960) was performed on all yeast-like colonies. The production of germ tubes within 90 mins. was taken as presumptive evidence of identification as Candida albicans. All yeast-like organisms failing to produce germ tubes in $90 \mathrm{~min}$. were tested for fermentation of glucose, maltose, sucrose, and lactose, each as 3 per cent. in peptone water, for pellicle formation in Sabouraud's broth, and for chlamydospore production on corn meal agar.

The Trichomonas medium was incubated at $37^{\circ} \mathrm{C}$. for $72 \mathrm{hrs}$ and examined daily for motile trichomonads. Any yeasts present were sub-cultured onto TTC medium and compared with the original TTC culture (indirect plating).

The smears prepared from cervical and urethral discharge were stained by Gram's method and examined microscopically for the presence of Gram-negative intracellular diplococci.

The G.C. Selective Medium plates were examined for the presence of Neisseria gonorrhoeae during an incubation time of $72 \mathrm{hrs}$ in a candle extinction jar (containing approximately 5 to 10 per cent. carbon dioxide) at $37^{\circ} \mathrm{C}$. Any oxidase-positive (Kovacs, 1956) colonies of Gramnegative diplococci were further tested for growth on nutrient agar at $37^{\circ} \mathrm{C}$. and at room temperature, and for fermentation of glucose, maltose, sucrose, and lactose, each in a concentration of 1 per cent. in 5 per cent. serum agar with Andrade's indicator. All tests were incubated in a candle extinction jar.

The cervical smears were stained using Papanicolaou's technique and examined microscopically for yeasts, trichomonads, and abnormal epithelial cells.

\section{Results}

625 pregnant women were investigated for the presence of candidiasis, trichomoniasis, gonorrhoea, and any other sexually-transmissible disease. Cases of candidiasis and trichomoniasis were analysed with regard to age, gestation, and parity. The results obtained by high vaginal swab and cervical cytology were compared.

405 of the 625 were analysed in greater depth. The relationship of candidiasis and trichomoniasis to marital and premarital or extramarital conception was assessed. The species of yeast isolated was determined. 284 of the 405 complained of a vaginal discharge and a clinical diagnosis was attempted (by R.A.S.).

\section{Candidiasis and trichomoniasis}

\section{CANDIDA}

171 of the 625 pregnant women had candidiasis (27.4 per cent.). In 108 Candida species were isolated from a high vaginal swab only; in 61 Candida was found in a high vaginal swab and in a cervical smear; and in two Candida was found in a cervical smear only. In only four patients were Candida and trichomonads found together $(2 \cdot 3$ per cent.).

\section{TRICHOMONADS}

29 of the 625 pregnant women had trichomoniasis ( 4.7 per cent.). In eight trichomonads were obtained from a high vaginal swab only; in eighteen trichomonads were found in a high vaginal swab and in a cervical smear; and in three trichomonads were found in a cervical smear only. In only four patients were trichomonads and Candida found together (13.8 per cent.).

In neither condition was the detection rate affected by age in itself, or by parity, but a significant difference is shown for gestation period. The detection rate for Candida is higher in the later weeks of pregnancy, i.e. from the 29th week.

100 out of the 405 analysed in more detail harboured Candida-predominantly Candida albicans (Table II). 93 of the isolations were present on direct

TABLE II Species of Candida isolated

\begin{tabular}{lll}
\hline Species & \multicolumn{2}{l}{ Isolations } \\
\cline { 2 - 3 } & No. & Per cent. \\
\cline { 3 - 3 } Candida albicans & 86 & 86 \\
Candida parakrusei & 7 & 7 \\
Candida krusei & 4 & 4 \\
Candida tropicalis & 3 & 3 \\
\hline Total & 100 & 100 \\
\hline
\end{tabular}


and indirect TTC plating. Seven were present on indirect plating only (Candida albicans 4, Candida parakrusei 2, and Candida krusei 1 . No Candida species grew on direct plating only.

There were 308 marital conceptions ( 76 per cent.) and 97 premarital or extramarital conceptions (24 per cent.) among the 405 women. The prevalence of candidiasis was comparable for both groups but trichomoniasis occurred significantly more often in the latter group (Table III).

TABLE III Prevalence of Candida and Trichomonas isolation related to marital status at conception

\begin{tabular}{|c|c|c|c|c|}
\hline & \multicolumn{4}{|c|}{ Conception } \\
\hline \multirow{3}{*}{ Organism } & \multicolumn{2}{|c|}{$\begin{array}{l}\text { Premarital and } \\
\text { extramarital } \\
97 \text { patients }(a)(b)\end{array}$} & \multicolumn{2}{|c|}{$\begin{array}{l}\text { Marital } \\
308 \text { patients }(c)\end{array}$} \\
\hline & \multicolumn{2}{|c|}{ Isolations } & \multicolumn{2}{|c|}{ Isolations } \\
\hline & No. & Per cent. & No. & Per cent. \\
\hline $\begin{array}{l}\text { Candida } \\
\text { Trichomonas }\end{array}$ & $\begin{array}{l}28 \\
10\end{array}$ & $\begin{array}{l}28 \cdot 9 \\
10 \cdot 3\end{array}$ & $\begin{array}{c}74 \\
9\end{array}$ & $\begin{array}{r}24 \cdot 0 \\
2 \cdot 9\end{array}$ \\
\hline
\end{tabular}

(a) Two patients had Trichomonas and Candida

(b) One patient had Trichomonas and Neisseria gonorrhoeae

(c) One patient had Trichomonas and Candida

In patients complaining of a discharge accurate diagnosis from the clinical findings was difficult, especially if candidiasis was present (Table IV).

\section{Gonorrhoea}

One case of gonorrhoea was diagnosed. This was in an unmarried 23-year-old woman in her second pregnancy. She had clinical trichomoniasis and cultures of the material from the cervical canal grew Neisseria gonorrhoeae. The cervical Gram film, the urethral Gram film, and the urethral culture were negative. It was subsequently found that she had attended the local venereal diseases clinic 6 months previously with gonorrhoea. She was treated at that time but did not attend for tests of cure.

One patient was negative on screening at 22 weeks gestation but subsequently gave birth to an infant who developed gonococcal ophthalmia neonatorum. The organism was then isolated from the cervix of the mother. She was a 31-year-old gravida nine, with at least six premarital conceptions. She was thought to be a prostitute and had attended venereal diseases clinics on at least two occasions, once for gonococcal salpingitis in 1968. She had become infected after screening.

\section{Other conditions}

One patient had scabies and three had condylomata acuminata. One of the latter had trichomoniasis.

Five women had positive serological tests for syphilis. Three were not substantiated on further tests, the fourth had an acute biological falsepositive Wassermann reaction, and the fifth was found to have previously undiagnosed congenital syphilis.

\section{Discussion}

Candidiasis is much commoner in pregnant women than trichomoniasis. The prevalence rate of candidiasis was 27.4 per cent. and that for trichomoniasis 4.7 per cent. In 169 of the 171 patients with candidiasis, the organisms were isolated from a high vaginal swab, but in 108 of these the organisms were not found in a cervical smear, and in only 61 patients (36 per cent.) were the organisms found in both a high vaginal swab and in a cervical smear. In only two patients was Candida found in a cervical smear and not in a high vaginal swab.

For the patients with trichomoniasis, however, a different picture emerges. In 26 of the 29 patients with trichomoniasis, the organisms were isolated from a high vaginal swab and in eighteen of these (70 per cent.) they were also found in the cervical smear; this is twice the detection rate found when smears were used to diagnose candidiasis. Three patients were found to have trichomoniasis on a cervical smear and not in a high vaginal swab.

Candidiasis and trichomoniasis together were found in only four of the 625 patients; 2.3 per cent. of those with candidiasis had trichomoniasis, and 13.8 per cent. of those with trichomoniasis had candidiasis. It is apparent from these figures that, as both infections seldom occur together, there is little justification for routinely prescribing expensive

TABLE IV Comparison of clinical v. bacteriological diagnosis of vaginal discharge

\begin{tabular}{|c|c|c|c|c|c|}
\hline \multirow{3}{*}{$\begin{array}{l}\text { Organism } \\
\text { isolated }\end{array}$} & & \multicolumn{4}{|c|}{ Complaint of vaginal discharge } \\
\hline & & \multicolumn{3}{|l|}{ Present (284) } & \multirow[t]{2}{*}{ Absent (121) } \\
\hline & & $\begin{array}{l}\text { Clinical candidiasis } \\
\text { diagnosed } \\
(\mathbf{4 8 )}\end{array}$ & $\begin{array}{l}\text { Clinical trichomoniasis } \\
\text { diagnosed } \\
(18)(a)(b)\end{array}$ & $\begin{array}{l}\text { Non-specific discharge } \\
\text { diagnosed } \\
(218)(c)\end{array}$ & \\
\hline $\begin{array}{l}\text { No, of } \\
\text { isolations }\end{array}$ & $\begin{array}{l}\text { Candida } \\
\text { Trichomonas } \\
\text { Nil }\end{array}$ & $\begin{array}{r}19 \\
2 \\
27\end{array}$ & $\begin{array}{l}6 \\
9 \\
6\end{array}$ & $\begin{array}{r}45 \\
5 \\
169\end{array}$ & $\begin{array}{r}32 \\
3 \\
86\end{array}$ \\
\hline
\end{tabular}

(a) Three patients with Trichomonas also had Candida.

(b) One patient with Trichomonas also had Neisseria gonorrhoeae.

(c) One patient had Trichomonas and Candida. 


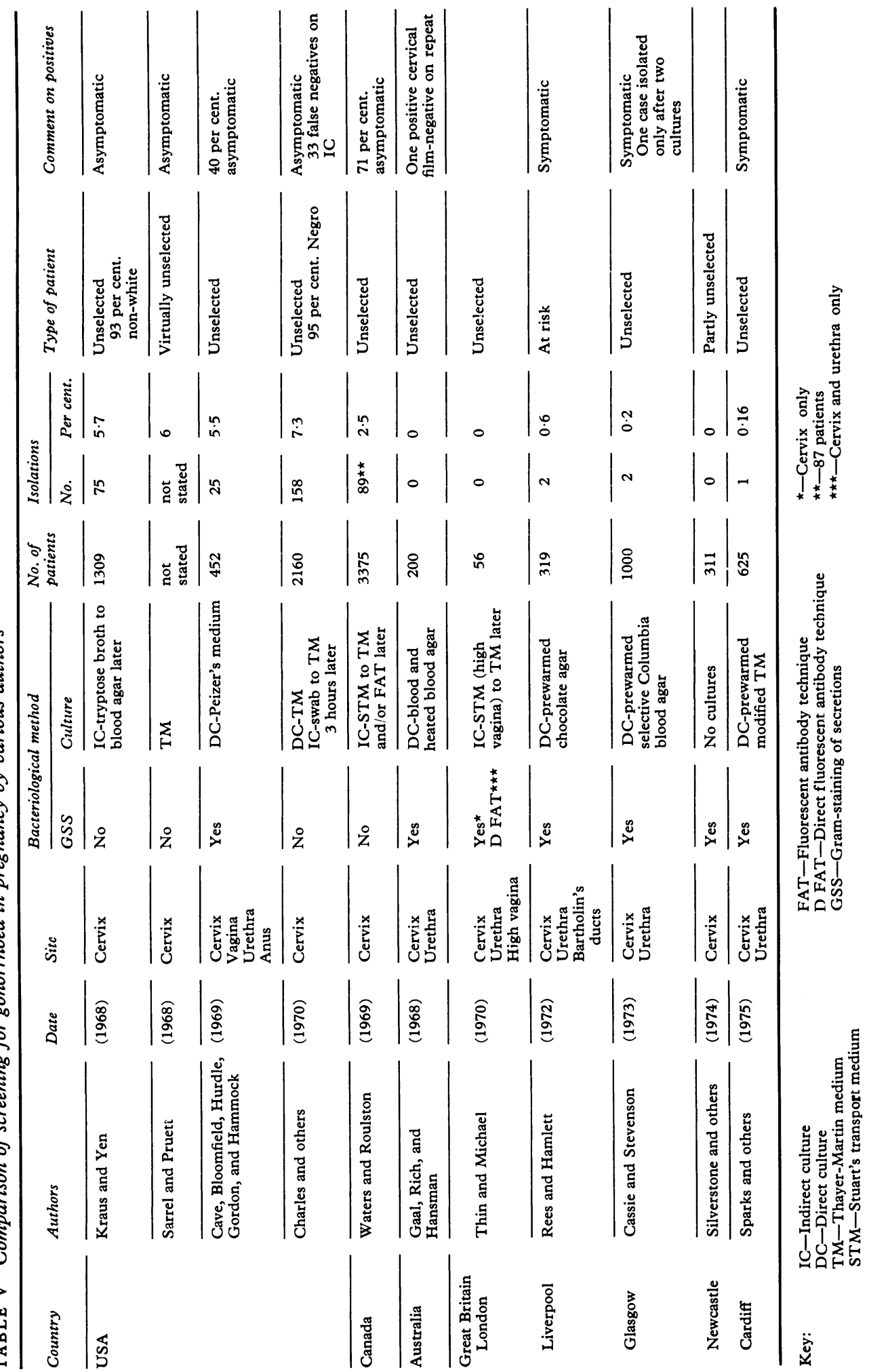


courses of treatment effective against both organisms. Once a patient has received an effective course of treatment for trichomoniasis, a repeat high vaginal swab should then be re-examined for the presence of Candida before treatment for the latter is considered.

The detection of Neisseria gonorrhoeae may be difficult and three negative sets of smears and cultures are needed to exclude gonorrhoea. Catterall (1970) found that 30 per cent. were missed on one set, 10 per cent. on two sets, but only 2 per cent. on three sets. He also noted that 55 per cent. of proven cases were asymptomatic.

Standard 10 per cent. chocolate agar plates are likely to be overgrown by organisms other than Neisseria gonorrhoeae, but Thayer-Martin selective medium containing colistin sulphomethate, vancomycin, and nystatin to inhibit their growth is superior (Thayer and Martin, 1964, 1966). Our plates were based on these with the addition of trimethoprim to inhibit Proteus species.

Lubricant was not used on the speculum as it may inhibit gonococci (Penza and Rankin, 1970).

Only one case of gonorrhoea was found, a prevalence of only 0.16 per cent. Difficulty arises in comparing other work because of geographical, racial, and socio-economic factors, as well as differences in technique and patient selection (Table V).

The rate of 0.16 per cent. is comparable with the findings of Thin and Michael (1970), Cassie and Stevenson (1973), and Silverstone and others (1974) in Great Britain. The higher prevalence of 0.6 per cent. found by Rees and Hamlett (1972) is explicable by their screening only patients 'at risk', whereas other workers and ourselves screened unselected patients. Indeed, they used chocolate agar plates and may possibly have isolated additional cases with selective medium. In all the British studies, the positive patients were symptomatic.

The high North American figures are noteworthy in that in most studies the infected patients were symptomless and a high number of those screened were non-Caucasian. They attended hospital antenatal clinics and are probably not representative of the population as a whole. Presumably Caucasian patients and those in higher socio-economic groups would seek private consultation and escape screening, thus making the samples not as unselected as they initially appear.

The Americans regard routine screening for gonorrhoea as essential, but the figures in Great Britain do not justify this. Direct screening is timeconsuming and would disrupt a busy antenatal clinic, especially if the recommended three separate sets of smears and cultures were taken.

A rapid serological test for screening large populations is desirable. The gonococcal complementfixation test is unreliable (Schofield, 1972) and recent comparison of the most promising alternative tests failed to find one which was satisfactory (Watt, Ward, and Glynn, 1971).

Fluorescent antibody techniques (Deacon, Peacock, Freeman, and Harris, 1959; Deacon, Peacock, Freeman, Harris, and Bunch, 1960) may have some advantage but are available at only a few centres. The recently introduced Transgrow medium, containing its own carbon dioxide enriched atmosphere and allowing the gonococcus to grow at room temperature, is at present undergoing evaluation. It has interesting possibilities for the outpatient clinic where a bacteriological laboratory is not immediately available.

We feel that, with present methods, direct plating onto selective medium is the best means of isolation. In its absence, charcoal-coated swabs placed in Stuart's transport medium should maintain viability of the gonococcus until it can be cultured (Moffett, Young, and Stuart, 1948).

We recommend screening for gonorrhoea the following 'at risk' groups :

(1) Patients with premarital and extramarital conceptions;

(2) Patients with a husband away from home for long periods;

(3) Drug addicts;

(4) Known promiscuous patients;

(5) Patients with a history of previous infection;

(6) Patients with trichomoniasis, as 50 per cent. of cases of gonorrhoea are accompanied by trichomoniasis (Catterall, 1970).

\section{Summary}

Gonorrhoea was not found to be a problem in antenatal patients. It was found in only one out of 625 women, thus confirming other British surveys which do not agree with the North American figures.

Candidiasis is commoner than trichomoniasis (27.4 and 4.7 per cent. prevalence respectively) and culture of a high vaginal swab is more effective as a means of diagnosis than a cervical cytology smear. The two conditions seldom occur together. The detection rate for Candida increases with gestation, but not with age, parity, or premarital and extramarital conception. The species isolated was predominantly Candida albicans.

Trichomonads are detected in culture of a high vaginal swab more often than in a cervical cytology smear. Detection does not increase with age, parity, or gestation, but does increase with premarital and extramarital conception.

It is difficult to diagnose clinically the cause of vaginal discharge in a pregnant woman.

We should like to thank Mrs. Patricia Goddard and Miss Rita Hughes for technical assistance, Mrs. Suzanne Curtin for secretarial help, and the staff of the antenatal clinic. Finally, we should like to thank Mr. R. C. Cummin for permission to perform this study on his patients. 


\section{References}

Albarracin, N. S., Jr., Patterson, W. S., and Daria Haust, M. (1967) Obstet. and Gynec., 30, 838

Cassie, R., and Stevenson, A. (1973) $\mathcal{F}$. Obstet. Gynaec. Brit. Cwlth, 80, 48

Catterall, R. D. (1970) Brit. F. Hosp. Med., 3, 55

CaVe, V. G., Bloomfield, R. D., HuRdle, E. S., Gordon, E. W., and Hammock, D. (1969) f. Amer. med. Ass., 210, 309

Charles, A. G., Cohen, S., Kass, M. B., and Richman, R. (1970) Amer. F. Obstet. Gynec., 108, 595

ChIEF MEDICAL OfFICER (1970) Brit. F. vener. Dis., 46, 76

,,$---(1974)$ Ibid., 50, 73

Crowther, I. A. (1962) Lancet, 1, 1074

Deacon, W. E., Peacock, W. L., Jr., Freeman, E. M., and Harris, A. (1959) Proc. Soc. exp. Biol. (N.Y.) 101,322

,,,---- , and Bunch, W. L. (1960) Publ. Hlth Rep. (Wash.), 75, 125

De CARNerI, I., and Di RE, F. (1970) f. Obstet. Gynaec. Brit. Cwlth, 77, 1016

GaAl, R., Rich, R., and Hansman, D. (1968) Med. f. Aust., 1, 634

Kovacs, N. (1956) Nature, (Lond.), 178, 703

Kraus, G. W., and YeN, S. S. C. (1968) Obstet. and Gynec., 31, 258

Litruewood, J. M., and KohleR, H. G. (1966) Arch. Dis. Childh., 41, 693

Moffett, M., Young, J. L., and Stuart, R. D. (1948) Brit. med. F., 2, 421

Penza, J., and Rankin, J. S. (1970) Clin. Obstet. Gynec., 13, 223

Rees, D. A., and Hamlett, J. D. (1972) f. Obstet. Gynaec. Brit. Cwlth, 79, 344

SARrel, P. M., and Pruett, K. A. (1968) Obstet. and Gynec., 32, 670

Schofield, C. B. S. (1972) 'Sexually Transmitted Diseases', 1st ed., p.132. Churchill, Livingstone, Edinburgh and London

SilvERSTONE, P. I., SNODGRASS, C. A., and WIGFIELD, A.S. (1974) Brit. F. vener. Dis., 50, 53
TASChdjian, C. L., Burchell, J. J., and KozinN, P. J. (1960) Amer. F. Dis. Child., 99, 212

Thayer, J. D., and Martin, J. E., Jr., (1964) Publ. Hlth Rep. (Wash.), 79, 49

,-- (1966) Ibid., 81, 559

Thin, R. N. T., and Michael, A. M. (1970) Brit. F. vener. Dis., 46, 126

Waters, J. R., and Roulston, T. M. (1969) Amer. F. Obstet. Gynec., 103, 532

Watt, P. J., WARD, M. E., and GlynN, A. A. (1971) Brit. F. vener. Dis., 47, 448

Détection pré-natale systématique de la candidose, de la trichomonase et de la gonococcie

SOMMAIRE

On ne trouva pas que la gonococcie soit un problème chez les femmes avant l'accouchement. Une femme seulement sur 625 fut trouvée gonococcique, ceci confirmant les autres évaluations britanniques, lesquelles ne sont pas en accord avec les chiffres Nord américains.

La candidose est plus fréquente que la trichomonase (27,4 et 4,7 pour cent de prévalence, respectivement) et la culture d'un écouvillon introduit profondément dans le vagin est plus efficace comme moyen de diagnostic qu'un examen cervical pour cytologie. Les deux affections surviennent rarement ensemble. Le taux de détection du Candida augmente avec la durée de la grossesse mais non avec l'âge, le nombre des grossesses ou le caractère extramarital de la conception. L'espèce isolée fut principalement le Candida albicans.

Les trichomonas sont trouvés par la culture d'un écouvillon profondément introduit dans le vagin plus souvent que sur un étalement cytologique cervical. La détection n'augmente pas avec l'âge, la parité ou la gestation mais augmente nettement si la conception a été extra-maritale.

Il est difficile d'établir nettement la cause d'une suppuration vaginale chez une femme enceinte. 